Thorsten Jochims*

\title{
Social reciprocity as a critical success factor for small and mid-size enterprises: Work relationships as reflections of social exchange structures ${ }^{* *}$
}

This study considers work relationships as social exchange relationships in small and mid-size enterprises (SMEs). It focuses on, in addition to economic determinants of exchange, the preconditions for and mechanisms facilitating the development of social reciprocity. Especially in SMEs, the integration of employees and the coordination of work tasks are determined by collectively developed and shared social rules and norms. The perception of the enterprise as a "collective project" represents an important success factor for internal cooperation.

Key words: SME, work relationship, social reciprocity, co-orientation (JEL: J23, J24, J28, M12, M54)

* Dr. Thorsten Jochims, Universität Lüneburg, Institut für Mittelstandsforschung, Scharnhorststr. 1, 21335 Lüneburg, Germany.E-mail: jochims@leuphana.de.

** Article received: April 30, 2015

Revised version accepted after double blind review: February 1, 2016. 


\section{Problem and method}

Small and mid-size enterprises (SMEs) face several challenges: For example, the shortage of skilled workers and demographic change can both have an adverse effect on the formation of internal work relationships. The willingness of employees to contribute to a given SME, to perform to the best of their ability, and especially to commit to a long-term working relationship with their employers may represent yet another major challenge. In relationships between employers and employees, which are all too often characterized by vagueness, both parties have to ensure an advance performance. The willingness to do so is likely to increase with the quality of the social relationship. The empirical study by Baron, Burton, and Hannan (1996) shows that money, love and work are central determinants for good work relationships. This study aimed to show that in SMEs, a functional social community can be of greater importance than monetary incentives and that violations of social reciprocity norms have an adverse effect on work relationships. In this article, we consider how reciprocal exchange relations can be fostered and how and to what extent constructions of social reciprocity contribute to this process. We show that especially establishing social exchange structures significantly improves the quality of work relationships.

In the empirical part of this study, we examine the phenomena under consideration with the help of selected case studies. We propose several assumptions, and these allow us to conduct a focused investigation of complex environments such as those of SMEs while simultaneously providing us with opportunities to consider and integrate connections that have not been regarded to be relevant. The preliminary theoretical considerations provide the framework of the study. In contrast to a "mono-theoretical analysis," which allows only for an interpretation of a given phenomenon in light of theory used, the observation of central mechanisms (Elster, 1989, and fundamentally Bunge, 1967) offers the distinct advantage of providing a more comprehensive explanation of the evidences that are observed.

\section{Work relationships in SMEs}

As Martin (2006) rightly points out, a work relationship is first and foremost a social relationship. A work relationship is also an exchange relationship. The two parties, employer and employee, do not act entirely altruistically (and in classic economic models, altruism is completely excluded) as they aim to bestow the expected rewards for performances on each other. Working relationships are, however, also characterized by asymmetrical exchange relations. Performances and rewards cannot be precisely located in temporal, spatial or content terms. The interests of employers and employees can, however, be explained by the theory by Bernard (1938), which was further developed by March and Simon (1958). According to Barnard, the situation of an organisation is always precarious and its survival only guaranteed by safeguarding the fragile balance between stimuli and contributions. The evaluation of the stimuluscontribution-relation is based not only on the actual performance of the players but also on the interpretation of the performance and an assessment of the situation. These kinds of assessment may lead to conflict and strain. What is significant for the functionality of the organisation is if, and in what form, the players invest time and ef- 
fort because they will get something in return, which is supported institutionally. Employees can rest assured that the organization values their contributions. In their study, Martin and Bartscher-Finzer (1998) identify work satisfaction as the goal of this exchange for employees and the commitment of the employees as that of the employers.

The basic conditions for this kind of exchange are not being constantly renegotiated in a work relationship; instead, there are structures that facilitate the process of exchange. According to Cyert and March (1963), the process used to determine the goals of a given enterprise works, in essence, through a mechanism involving fixed exchange structures. Despite the fact that the meaning of social relationships is emphasized multiple times in stimulus-contribution-theory, the "social" element finds little accord in the respective research. Berger and Bernhard-Mehlich (2006, p. 183) note that the processes by which diverse and sometimes competing expectations of different protagonists involved in organizational decision making are being reconciled are usually invisible. While the behavior of the players in accordance with the economic rationality principle contributes to the balance of the system in a given organisation, the assurance of reciprocal exchange relations is much more important. In a functional work relationship, institutional arrangements and fixed relationship patterns are also embedded socially. The "social" functions not only as an "exchange object" but forms the framework for the interpretation of a situation in which the players attribute a subjective value to exchange objects. A social work relationship promotes the appearance of a general perception concerning the extent to which the organization values the general contributions of employees and cares for their well-being (Eisenberger, Armeli, Rexwinkel, Lynch, \& Rhoades, 2001).

\subsection{Patterns of exchange relation}

The study by Baron et al. (1996) provides a first glimpse of the institutional exchange patterns that can be observed in reality. Focusing on the Stanford Project on Emerging Companies (SPEC), the authors examine young enterprises in Silicon Valley with a distinct emphasis on their organisational structures and the challenges experienced by their HR management. The authors identify distinct patterns (blueprints) of work relationships in their study. The factors that define the patterns of these organisations and that were addressed with the help of specific HR management strategies are the following:

- Money (monetary stimuli)

- Love (emotional and familial connection)

- Work (challenging occupation and autonomy)

Since the enterprises investigated in this study were high-tech companies based in Silicon Valley in the USA, these determinants of development of personnel-political patterns have to be reconsidered in light of the focus of the present study, namely midsize enterprises in Germany. In the following, we will slightly expand the perspective of Baron et al. and adjust their constructs so that they can be used to examine the specific requirements of SMEs. When it comes to the issue of money, we focus on the economic components of work relationships. Employees work to earn a living, but it 
is important to note here that the factor money not only involves wages or salaries, but also all other monetary advantages, for example free or subsidized childcare or cafeterias. A crucial dimension of economic exchanges is fairness. How do employees evaluate their exchange relations? In this respect, their expectations, which are mainly the result of a comparison to possible alternatives, are essential. The issue of job security, that is, the guarantee that the economic benefit of the relationship will continue in the future, is likewise described by the factor money. This issue is of particular importance for the present study, as SMEs do not, especially compared to larger companies, provide high salaries (Martin \& Behrends, 2005) but can attract potential employees because they are characterized by higher levels of job security.

A study by Kotthoff and Reindl (1990) is a good starting point to describe the factor love, the main object of study in the present paper. In their qualitative study, the authors investigate the characteristics and modes of action of the social system in over 50 SMEs in Germany. According to Kotthoff and Reindl, a specific social system determines the development of informal rules and largely affects the coordination of action within the organisation. The authors characterize a successful small or mid-size enterprise as a collective project of all those involved, as a "social togetherness," and employees conceive of themselves as belonging to the enterprise (1990, p. 354 f.). Thereby, a "feeling of togetherness", and a high loyalty of the employees towards the organization arise. Despite the focus on performance, interaction stays humane, everyone respects another and the work relations are determined by mutual consideration of another. Small or mid-size enterprise can be characterized by this sense of togetherness, which is premised on mutual trust of all parties involved, but there are also those defined by instrumental relationships. These enterprises can be economically successful, but more often than not, they are limited in their potential due to rather dissatisfied employees ("soulless workhouses"). In these relationships shaped by instrumentalisation, there is often mutual lack of trust amongst the parties involved.

Martin (2003, p. 128) defines trust as a reciprocally grounded, generalised expectation, and this understanding of trust plays an important role in SMEs. What does the process of creating a generalised expectation look like? Developing mutual, nonpredetermined expectations is not an easy task, and the inherent difficulty becomes obvious if one considers the concept of the psychological contract (Rousseau, 1995). Trust and fairness, justice and appreciation are the basis of healthy exchange relations. Transparency, effective communication, and a clearly defined work processes indicate what is expected from all parties involved. Values and norms have crystallised into, for example, specific practices during a long process, and employees pass these on to new ones. As a collective project, the enterprise aligns the individual goals of the parties and suggests a common direction. Goodwill is solidified through the integration of the enterprise into the environment of employees and employer. In many cases, relatives, neighbours or friends work together in SMEs. People are acquainted with one another because they also interact in other social context, for example, sport clubs or professional associations. These kinds of close relationships foster the formation of trust, although the related dimension of social control may be experienced as uncomfortable. 
According to Baron et al., the third important determinant for the integration of employees is work. In contrast to Baron et al., we use a broad definition of the term, which also includes what we would describe as work sense or the meaningfulness of work. As mentioned above, employees may conceive themselves as members of a collective project, as integral parts of the enterprise. If that is the case and if employees contribute to the success of the company through their actions, then their actions are meaningful to them and they experience sense in doing their work. This can be understood as self-actualisation, especially when related to the workplace. Here, selfactualisation is not understood as a key feature of the "culture of narcissism" (Jaeggi, 2005 , p. 243), in which individuals improve their skills to pursue a career. In the present study, the term self-actualisation is used for employees who realize their potentialities in their work, work that they do based on a free decision (Kambartel, 1989, p. 24).

This kind of work does not necessarily have to involve particularly important or difficult tasks. Meaning is assigned to these tasks by the individuals who complete them, and not based on from outside given criteria. Employees perform the tasks for themselves, not for others. To illustrate this phenomenon, Sennet $(2005$, p. 84$)$ points to concierges, who tend, despite poor working conditions, to be satisfied with their occupation and to find meaning. In terms of content, the factor work can also include possibilities for personal or professional development. When individuals have these possibilities, they are, we argue, more likely to evaluate their occupation positively.

\subsection{Social reciprocity}

Work relationships are not only about the sense of situational and momentary satisfaction derived by employers or employees. The nature of these relationships and, more specifically, the balance of giving and taking, are important. Therefore, the question of social reciprocity of exchanges is crucial, especially because work relationships are still only vaguely defined in several contexts.

Social reciprocity is, according to Gouldner (1984, p. 96), a generalised moral norm. The economic principle stipulating that each player wants to maximise his or her benefit does not apply here. Performance and reward are not calculated but bestowed due to a morally felt obligation. Voswinkel (2005) argues that social reciprocity produces loyalty and performance dedication. In his view, theories concerning the efficiency of wages do not adequately explain the relation between wages and the commitment of employees. Employees are more likely to contribute to a greater extent if employers also offer rewards. Since performance and reward are never specifically determined, they require social definitions, and these are also collectively developed. It is not solely the individual employee who owes the performance but employees as a collective. However, social reciprocity develops only when two conditions are met:

1. Long-term: The partners' trust in their performance can only be reciprocated in permanent and stable relationships.

2. Work ethics: Those who only think about their own advantage are not suited for reciprocal relationships.

In reciprocal relationships, an expected effort already leads to the recognition of performance. The effort is what is accounted for, not the success. What is striking is the 
lack of a direct "offset" of performance. If the relationship is, general, experienced as reciprocal, neither employers nor employees are likely to evaluate performance in terms of potential or actual awards. Both parties provide performance in advance and even experience good feelings while they do, as long as they can trust in the fulfilment of their expectations. The basic rules of the relationship must not, however, be violated. The social definition of the situation in reciprocal relationships is, on the one hand, a strain but, on the other hand, the resulting conflicts create connections and identities through social exchange. Tajfel (1982) also emphasises the identity-forming effect of the group within the theory of social identity (see also Ashforth \& Mael, 1989). The parties are considerate of one another and show true interest in the partner. Everything happens humanely, the exchange amongst one another leads to the reproduction of a sense of belonging to the organization (Voswinkel, 2005).

The general performance of an employee is thus highly dependent on the reining reciprocity norms in the organisation. The employee always supports the organisation through necessary work behavior when he too has the feeling that he can rely on the support of the organisation concerning his own interests. Such connections have already been proven in studies about "perceived organizational support" (POS). POS describes the special social relationship in the organisation. To what extent can the employees trust that their efforts for the organisation will pay off in the long run? Perceived organizational support is therefore " $\ldots$ a general perception concerning the extent to which the organization values general contributions and cares for their wellbeing". (Eisenberger et al. 1990, S. 51) Are the employees only assisting to maximise the company's profit or does the employer voluntarily take care of the employees' wellbeing without expecting a direct service in return? In general, the meta-analysis by Eisenberger/Rhoades shows that POS has a positive effect on work behavior. „Our review of over 70 studies suggests that basic antecedents of POS include fair organizational procedures, supervisor support, and favorable rewards and job conditions and that consequences include increased affective commitment, increased performance, and reduced withdrawal behaviors." (2002, S. 712). Moorman, Blakely, and Niehoff (1998) prove the positive connection of POS and OCB in particular.

Further advantages of a reciprocal work relationship are described i. a. in the study by Tsui, Pearce, Porter, and Tripoli (1997). The authors investigated relationships that are founded on mutual exchange, control through superiors and control through colleagues (peers). The reciprocal exchange reveals itself as the form of coordination with the highest achievement potential. It is important to note here that a relationship shaped by the overinvestment of the employer has been shown to have a lower performance capability. The overinvestment of the employer leads to the development of distrust amongst employees ("too good to be true", p. 1115).

\subsection{Engagement}

While the discussion of social reciprocity focuses on the "spirit of exchange relation," we want to take a quick look at the exchange partners. As suggested by stimuluscontribution-theory, a good employee is characterised by his or her dedication and the willingness to meet additional requirements. A good employer, in contrast, seeks to make this relationship attractive to employees through his behavior, and he or she fos- 
ters the satisfaction of his or her employees. While the number of studies on employer behavior is still very limited (Wächter, 2011), there are many concepts that could be used to describe what an employee needs to do in addition to the duties required due to his contractually fixed occupation (Hertel, Bretz, \& Moser 2000). A common concept that takes a closer look at the commitment of the employees is proposed by Organ (1988). In the context of the "organizational citizenship behavior" (OCB), he focuses on the specific issues of performance. OCB includes services by employees, which go beyond their contract and formal working role. Similarly to the reciprocal work relationship, this behavior depends on the reward promised or given by the employer. As a "good citizen," the employee is expected to perform special additional services. The organisation must encourage this behavior through the creation of a reward system and by fostering social reciprocity in the organisation ("sense of citizenship") (Organ, 1988, p. 22). Organ first defines altruism and general compliance as content of the OCB. He then adds courtesy, civic virtue and sportsmanship to the concept. In addition to OCB, similar concepts like Prosocial Organizational Behavior (Brief \& Motowidlo, 1986), Organizational Spontaneity (Brief \& George, 1992) and Contextual Performance (Motowidlo \& van Scotter, 1994) have been developed.

As mentioned above, employees do not perform altruistically. They expect a "sense of citizenship" in return. But what is the "company substrate" for the creation of this kind of commitment? What kind of employer behavior fosters the development of a good work relationships and, thereby, the OCB?

\section{Empirical analysis}

The present study focuses on the description and explanation of a social phenomenon, namely the occurrence of functional exchange relations. "In other words, you would use the case study method because you wanted to understand a real-life phenomenon in depth, but such understanding encompassed important contextual conditions - because they were highly pertinent to your phenomenon of study." (Yin \& Davis, 2007) The main research question concerns the criteria for reciprocal work relationships in SMEs. More specifically, it seeks to identify the performances by employers that are the prerequisite for employees to grant what we describe as performance credit. Most of the previous studies tend to consider only the performance expected of employees. However, under what conditions are employees willing to work for the enterprise voluntarily, without direct reward? In other words, which conditions must be met if one seeks to establish a relationship from the basic exchange of performance for reward? To answer these questions, three hypotheses were developed. These hypotheses are derived from the discussion of major theoretical and empirical concepts above. Kotthoff and Reindl emphasize that "social relatedness" to the organization is a central element of coordination of action (1990, p. 243). The connection between a $\mathrm{CEO}$ and his or her employees is established in the context of a specific enterprise. The goals of this enterprise are derived from this relationship. It is not the goals that shapes the relationship; instead, the relationship affects the identification of goals or, perhaps even more so, the acceptance of goals. In their study, Bateman and Organ (1983) also find that social factors in organisations have a stronger positive effect on work satisfaction and OCB than wages or occupation. The "social element" in the 
work relationship cannot be replaced arbitrarily (substitution hypothesis); the work relationship is not centrally dominated by a spirit of opportunism. The "social element" moulds both actions and thinking of all parties involved (Martin, 2011). The definition of the situation, in turn, is determined by the framework of the relationship ("sense of citizenship"). Performance and reward are subject to constant interpretation and negotiation by the two parties involved, which is defined by the specific, applicable norms of social reciprocity. The following three hypotheses describe this phenomenon in greater detail:

1. "Social Hypothesis"

Of the three factors (work, love, money) named above, the concept of social reciprocity (love) is of central importance for employees at SMEs.

2. "Substitution Hypothesis"

The basic conditions of a functional work relationship (work, love, money) cannot be arbitrarily substituted. A lack of love in a relationship cannot necessarily be compensated with more money.

3. "Attribution Hypothesis"

The performance of employees (and their commitment) depends on the ability to allocate a reward. The HR policy of the enterprise is of great importance in this respect.

\subsection{Method}

The data analysed in this study was generated during a research project involving comprehensive case studies conducted in seven SMEs between 2012 and 2014. Brief descriptions of these SMEs are provided in the table below. All of these enterprises are located in Northern Germany.

Table 1: Overview of case studies

\begin{tabular}{l|l|c|c|c|c}
\hline Case study & Occupation & $\begin{array}{c}\text { Category no. } \\
\text { of staff }\end{array}$ & $\begin{array}{c}\text { no. of qualita- } \\
\text { tive interviews }\end{array}$ & $\begin{array}{c}\text { Additional } \\
\text { survey }\end{array}$ & $\begin{array}{c}\text { Participation in addi- } \\
\text { tional survey, no. }\end{array}$ \\
\hline Health & $\begin{array}{l}\text { Production and trade } \\
\text { of tea and cereals }\end{array}$ & $250-499$ & 15 & No & \\
\hline $\begin{array}{l}\text { Building } \\
\text { materials }\end{array}$ & $\begin{array}{l}\text { Wholesale of building } \\
\text { materials }\end{array}$ & $55-99$ & 9 & No & \\
\hline Agriculture & $\begin{array}{l}\text { Wholesale of packaging } \\
\text { material }\end{array}$ & $25-49$ & 7 & No & \\
\hline Candy & Production of sweets & $100-249$ & 11 & Yes & 91 \\
\hline Bonus I & Automobile supplier & $100-249$ & 8 & Yes & 192 \\
\hline Bonus II & Internet provider & $50-99$ & 5 & Yes & 58 \\
\hline Technology & $\begin{array}{l}\text { Medical technology } \\
\text { producer }\end{array}$ & $100-249$ & 10 & Yes & 147 \\
\hline
\end{tabular}

1 In some case studies, an additional quantitative survey of central facets of work satisfaction was conducted. The investigation is not directly connected to the interviews; however, individual results of the standardised questionnaire could be used for the validation of the interview results. 
Comprehensive semi-structured interviews were conducted with representatives of employers (CEOs, HR executives) and representatives of employees. The interview partners come from all levels of hierarchy and areas of activity in the enterprise. The interviews were first evaluated, and then the main results were presented and discussed with the interview partners (partially in groups) in order to communicatively validate initial findings. In the following chapters, central statements from the interviews will be repeated to illustrate and substantiate key points. The comments are not representative for all interviewees, but were chosen in such a way as to convey the main impression left by interviewees. The seven case studies were not conducted systematically based on previously fixed criteria. Therefore, the possibility of finding other and perhaps even anomalous results cannot be ruled out.

While the method of empirical mass surveys (data mining) can often only be used to describe surface phenomena, the case study design permits deeper insight into the research field, and, furthermore, it allows for an analysis of the contextual factors of the connections that are investigated in the present study (Pongratz \& Trinczek, 2010). The use of these case studies, an approach that was even partially supported by participant observation, allowed for deeper insights concerning the connections of work relations in SMEs (Jochims, 2010). Methodically and conceptionally, our case study design is based on the definition of Yin (2014): "A case study is an empirical inquiry that investigates a contemporary phenomenon in depth and within its real-life context, especially when the boundaries between phenomenon and context are not clearly evident" (Yin, 2014, p. 18). To meet the quality criteria of empirical research (validity and reliability), we follow the requirements for case study design as proposed by Yin $(2014$, p. 40).

In addition to the methods described so far, we also employed the critical incident technique (Flanagan, 1954). Particularly the questions concerning situations in daily work life, which were experienced as especially burdening, or more precisely, which disturbed the balance of the work relationship, required employees and employers to reflect on the context of their actions and to offer their interpretation of the situation. The goal was to become more immersed in the world that the employees experienced. Moreover, the critical incident technique is also compatible with the design of our semi-structured interviews: "It should be emphasized that the critical incident technique does not consist of a single rigid set of rules governing such data collection. Rather it should be thought of as a flexible set of principles which must be modified and adapted to meet the specific situation at hand" (Flanagan, 1954, p. 355). The interviewees were also asked to recount events that were positive. The goal was to describe the quality of the work relationship as perceived by the interviewees. To further strengthen the validity of the statements, participants were asked to clarify important statements using examples of their choice. Some chose metaphors such as "We feel like step-children here...the good father is just missing...we are always the stupid ones that everyone here picks on..."

When using this method, it is important to avoid tactically or socially desired statements, i.e., to identify them in order to gain access to more specific accounts or to understand the context by asking additional questions. 


\section{2 "The good employer"}

At first, the main research question addressed in the present study was how employers can create and foster a climate that can contribute to the development of an OCB among employees. Starting from the hypothesis that a reward system, regardless of its design, cannot function as a mere substitute for OCB, we investigated the possibility of a kind of "OCB-behavior" by employers.

Concerning the quality of the work relationship and the expectations towards employers, the following five areas were identified:

- Social reciprocity (feeling of togetherness)

- Trust

(honesty and obligation)

- Orientation

(clear structures, work relief)

- Identification

(role clarity and commitment)

- Leadership

(personal engagement and passion)

As suggested by Kotthoff and Reindl (1990), the desire for social reciprocity is an important requirement for work relationships in SMEs. Proximity is expected by employees, and statements such "we down here - they up there" are, rather, indications that work relationships are, to employees, unsatisfactory. What becomes clear from this finding is that, for example, employees who used to work for large companies before they were hired by SMEs tend to have expectations concerning social reciprocity at their new place of employment. To these and other employees at SMEs, social reciprocity also means that each person is important and is perceived as an individual human being with distinct personal needs and abilities. In response to the request to describe an event that had impressed them, almost all participants recounted situations in which employees were treated as human beings and were shown consideration by other employees and by employers. The following statement by one of the participants describes this kind of experience: "Mr. (Researcher), you won't believe it, at the party the "boss" from Holland came up to me at the bar, addressed me by my name and asked how I'm doing (...) and said he really wants to know how I am because all his employees are important to him. We're just a family." Participants indicated that employees do not want to be cogs in a machine but contribute to the success of the enterprise and receive honest responses concerning their contributions. The enterprise is a project that is important to them as individuals. Despite a wide range of conflicts, for example those related to the distribution of resources, employers function as partners in the day-to-day activities of the enterprise. If the daily struggle of doing one's best for the enterprise as a whole changes to primarily a fight against other employees or employers, this shift also has an adverse effect on employees. As indicated by Kotthoff and Reindl, employers may unilaterally withdraw from the work relationship in these kinds of situations. In contrast, employees may still hold on to the ideal of social reciprocity much longer.

The employees at the SMEs examined in the present study do not, however, believe that work relationships do not have to constitute a community in which each member is entitled to comfort, and they may even reject such forms of social reciprocity. As one participant put it, "Before, we would really fight. The current managers 
don't know this and, sadly, they don't want it either. In the past, we would argue and sometimes didn't speak with another for days but then we came to an agreement and accepted the solution. In today's meetings, conflicts are quickly discontinued, decisions postponed and weeks later they are discussed again without results." The struggle to develop a collective project can indeed be a major source of conflict. The lacking aversion of employees in conflicts can result from the special manner in which they are socially embedded. Employer ensure job security, and this is acknowledged by employees. In one enterprise, the median of all questioned employees concerning the question, "What does the executive management do to secure jobs?" rated the employer's effort, on a Likert-scale from 1 to 7 , where 7 is the maximum value, at an astonishing 6.4. The employees have a healthy sense of self-confidence. Since employees often have a good understanding how the enterprise functions, they can assess their contribution and their individual progress. The feedback on work performance is given through the work itself, and employees are not dependant on the recognition of their superiors. That said, mutual appreciation and support are, as suggested by one of the participants, regarded highly: "One is there for each other and does not abandon another."

The employees who were interviewed regarded trust in a work relationship as very important. They indicated that they wanted employers to behave honestly and communicate clearly. These employees mainly criticized that communication by employers seemed to be too calculated. To them, managers did not say what they think openly but tried to achieve their goals through skilful communication. This observation was made by several participants in the study: "Communication is too tactical instead of open, honest and authentic"; "Too often, communication happens based on management-handbooks"; or "Management is afraid to tell us the truth." This kind of communication not only erodes employees' trust in superiors but also increases their sense that they are not taken seriously: "We are adults, we can handle the truth." "We know what is happening anyway, they don't have to protect us." Most of the participants also expressed their desire for clear and honest feedback ("one has to be able to speak one's mind"). Trust is perceived is indicator of good collaboration. For the employees at the SMEs examined in this study, the authenticity of their superiors is an important factor for fostering the development of trust. Superiors should not only admit their mistakes; they are also allowed to make them. Superiors that pretend to have competences that they actually do not have are frowned upon. The daily social community in enterprises results in giving all parties a very good sense of what others can and cannot do. Employees accept the weaknesses of superiors but demand honesty. Conversely, the employees demand a strong identification with the enterprise and the profession by superiors. One of the main findings resulting from these interviews is that "one can trust another." Expectations are reciprocal and known by all parties involved, and infringements are collectively sanctioned. Not only employers and management, but also employees aim to make sure that these expectations are being met. At the same time, there is a great courtesy.

In contrast to recommendations in some textbooks, the employees at the SMEs examined in the present study do not believe that employers have to motivate. Instead, they expect the provision of orientation and, thus, work relief (Martin, 1998). One 
of the surprising findings of this study is that there seems to be a strong focus on the entrepreneur or individuals most closely associated with the enterprise, when there are problems. Although they independently work on difficult and significant issues, employees still tend to turn to the entrepreneur in these kinds of situations. Employees seem eager to look for, even demand, an exchange with the entrepreneur. This tendency is summarised by one of the participants as follows: "He should say what is going on." Entrepreneurs are regarded as figures of authority or leaders, and employees do not expect what they described as "nice soapbox rhetoric", but they expect to be addressed clearly. The entrepreneur is the one who stands for his or her enterprise, who can be trusted and who will unconditionally commit himself or herself to the collective project. The entrepreneur is a role model, and his or her commitment and passion for the enterprise can impress and motivate employees. If there is no commitment or enthusiasm, the enterprise may even face an identity crisis.

The enterprise stands for specific values and norms, which are either held or associated with the entrepreneur or his or her family. Even when these values appear, in part, to be extreme and bizarre to outsiders (such as researchers), employees appreciate the guidance that they provide. In one enterprise, the entrepreneurs, a couple, made sure that all cups and glasses had special coasters and saucers so the furniture would not be stained. Even though the majority of employees found that this measure was exaggerated and dismissed it with a smile, the reputation of the couple did not, as the following quotations indicate, take a hit: "They take care of the enterprise and the enterprise is important to them." "Being friendly to the customers is important to the folks (the entrepreneurial couple), that is our central value. And even if some of that seems over-the-top today, this is us, I don't have to like all of it but the general direction is good."

The values of the enterprise do not remain abstract; they become specific as employees and entrepreneurs in particular lived by them. To the question of why he would not introduce controlling despite having around 250 employees, an executive and founder of an SME replied, "I don't tolerate nitpickers that run around and make my people nervous. Everyone here works well and I can trust my employees." The reasons given here are important, and this statement provides further evidence that authenticity is, as mentioned above, important when it comes to work relationships. The CEO does reject controlling because it goes against his demand for reciprocal trust. Orientation means clarity and obligation in goals and values. Already a small number of individuals embodying the values of the enterprise can guide employees and their actions.

Identification is another criterion that can be used to assess the quality of a work relationship. As suggested above, employees want to identify with humans. The entrepreneur and the executive management ideally function as role models. Personal commitment depends on that of the superior. In the case studies, which were supplemented with quantitative data, the medians of the standardised surveys showed high levels of connection to the enterprise and concerning the item "Proud of the enterprise." The interviews provide further evidence for the central role of prominent individuals in enterprises. When they fight for their enterprise, devote themselves to the enterprise and their employees, employees are more likely to identify with these per- 
sons and the enterprise. This identification with people may eventually also include the entire organisation. As one interviewee put it, "I owe so much to Mr...I will always be connected to this enterprise. My identification is so strong that it can't be shaken by anything." Researcher: "But Mr... has been succeeded in this enterprise years ago." Employee: "That doesn't matter, for me he is the enterprise, no matter who leads it now, the values remain." The identification has a lasting effect, and successors may stand in the entrepreneur's shadow. Successors have to show that they deserve the trust of the employees. In this respect, technical competence seems less important than personal dedication to the enterprise and authenticity, which may increase the acceptance of the new leadership and strengthen identification. Thus, commitment does not primarily develop through the congruence of employees' personal goals with abstract enterprise goals but through the consensus of enterprise and employee goals.

Leadership based on numbers, statistics and commonly used management principles is a nightmare for the employees at SMEs investigated in this study. They expect leadership with the heart and not of the head. Superiors need to understand how the enterprise works, should acknowledge the contributions of employees and consider their daily problems. Ideally, a manager would be "one of them," personally respond to employees and also contribute to the success of the enterprise as a whole, not advance his or her own career. The participants in the case studies rejected a management only based on management ratios. Ideally, management allows employees to participate in decision-making because they appreciate them and regard their opinions as important, not because participation is the newest management fashion and also not to placate the staff. Leadership can be "uncomfortable," and even obstinate superiors may earn respect if employees can argue with them. Ambiguous statements by the superiors are met with resistance and are regarded as a sign of weakness. The employees interviewed for the present study did not want a coach or mediator as a superior; they want a person that represents their values but especially the enterprise.

It is likely that there are other aspects that foster an OCB among employees. This study aimed to identify the main factors affecting the commitment of employee. As the interviewees indicated, creating the conditions for a successful work relationship is not the sole responsibility of the employer but of all those involved. The collective project and the related work relationships can only function properly when all do their part.

\subsection{Social reciprocity as a success factor?}

Our initial assumption concerning the work relations in SMEs, which are characterized by reciprocal exchange relationships and a "sense of citizenship," was that these relations are primarily determined by love. By deriving and testing this hypothesis, our assumption not only became more specific, but our analysis of the data generated during interviews also provided evidence for this distinct dimension of social reciprocity and related issues such as leadership or trust. This finding is particularly striking considering that one of the enterprises examined in the present study, which does not emphasize the factor of social reciprocity in its HR policy, has the lowest work satisfaction and suffers from many internal conflicts (e.g. a high workforce fluctuation). In 
addition, our data clearly showed that when work, love, money is under a critical level, the work relationship tends to be strongly and negatively influenced. In the following, we describe the results of three case studies that augment our initial hypotheses on the level of content.

\section{Social hypothesis - The case study "Building Materials"}

The enterprise examined in this case study trades with building materials. This enterprise was of particular interest to us because it gave us the opportunity to conduct a group interview with three employees who had indicated that they viewed the enterprise's development very critically. For this reason, one of the main findings, namely that employees seemed rather satisfied with their work in general and work autonomy and the development of their wages in particular, was unexpected. Only the development of social relations in the enterprise was cause for great concern and dissatisfaction. It is important to note here that the interviewees distinguished between their work satisfaction (consistently positive ratings) and satisfaction concerning their work relationships (extremely negative ratings).

A few years prior to the interview, there had been a change of executive management in the enterprise. Although the former CEO had been perceived as very dominant and "imperious" and the new management was perceived to be more human, there was barely an end to the complaints of the three interviewees about the new management. These complaints were primarily related to what was described as "distancing from the employees" and "the lack of personal exchange" between the two parties. The ambivalent relationship to the former CEO turned out to be, in hindsight, more satisfying than the one to the new managements, which, at least according to the executive management, is characterised by objectivity and professionalism (i. e., leadership based on numbers). As mentioned above, not only factual exchanges contribute to the success of the enterprise, but also, and perhaps even more so, social interaction, which also fulfil important affective need of employees.

\section{Substitution bypothesis - The case study "Candy"}

In the second case study, the employees turned out to be very unhappy, and they complained about the lack of social reciprocity in particular. They felt that they were undervalued and that their contributions to the success of the company were not acknowledged. The executive management reacted to this growing dissatisfaction with expensive material gifts to alleviate the general dissatisfaction. Despite these gifts, the level of satisfaction decreased even further, and some employees even rejected the gifts. As a result, the CEO did not understand the "ungrateful" employees anymore. The lack of social reciprocity has continued, adversely affecting the perceived quality of the work relationship. As one of the employees put it, "Before, the boss was still interested in us. During extra shifts on the weekend, he was working himself and brought schnitzel." "He still had an open ear for us, he was the good father, now we're nothing to him, the main issue is profit." These statements suggest the current lack of concern and personal interest by the "boss" for his employees. To them, the considerable difference in terms of cost between material gifts and schnitzel is of no importance, as the expected social interaction with their employer has come to an end. 
Instead of engaging with his employees during shifts on the weekend, the boss tries to appease his employees with material gifts.

As this example shows, one of the basic building blocks of working relationships cannot simply be replaced by another. Money is no substitute for love. Through the social interaction resulting from collaborative work and shared meals during the shifts on the weekend, the relationship can be improved, and the employer can demonstrate genuine interest in the people working for his company. The various performances cannot be added together, and one action cannot be offset by another. There appears to be a basic need for work, love and money, which is articulated and demonstrated in differing ways depending on the type of work relationship. Within certain limits, employees tolerate deviations from the norm. However, at some point, there will be "turning points," and once lines have been crossed, the likelihood of a slump in work satisfaction increases considerably.

\section{Attribution bypothesis - The case study "Bonus"}

Exchanging performance for reward! Sadly, work relations are more complex than this catchy phrase suggests, and the exchange is often not associated with defined individuals. This lack of attribution can be a considerable problem, as people cannot express or display gratitude. Higher wages may be required by labour agreements (and therefore cannot, for example, be interpreted as a gift by the employer), and other rewards likewise remain hidden. The value of rewards strongly depends on the interpretation by the recipients. A reward is only one if it is perceived as such. For this reason, the interpretation of the related context or situation is crucial (Martin, 2011). In this and other situations, the personnel policy of the enterprise functions as a cognitive, affective and conative framework for the situation's interpretation.

Similar situations can, however, be interpreted differently and lead to very different responses. We compared two enterprises, in which an annual bonus payment was much lower than promised. In enterprise A, there is an instrumentalist social order, and the level of social inclusion of the employees is low, and mutual distrust can be observed. In terms of HR management, the emphasis is on the economic exchange between employer and employees, and cooperation only takes place as long as direct benefits can be obtained. Enterprise B, in contrast, seeks to integrate its employees and is characterized by a collective social order. The relationships are characterised by mutual trust, and the employees do not merely work there but are full-fledged members of the organisation.

When the annual bonus failed to materialise as expected in the two enterprises, work satisfaction in enterprise A was reduced but remained essentially unchanged in enterprise B. In both enterprises, the balance of stimuli and contribution was disrupted. However, in enterprise B, wages are not perceived as important as in enterprise A, because the relationship is not primarily built on monetary stimuli, and the employees are more likely to believe that the lack of bonuses is justified and likely to remain an exception. Such deviations are forgiven as long as the basic orientation is fine. However, it is possible that if the bonus would fail to materialise again, employees may respond very differently to this situation: In enterprise A, negotiations about compensatory payments would take place. The employees in enterprise B may suddenly react 
very emotionally and would be very dissatisfied. The relationship would be shaken in its foundations, as employees would feel that their trust had been abused. The missing inclusion concerning this decision ran counter to the HR management practices of the enterprise. Individual measures only develop their effect through the interpretation of the people who are affected by them. Actions are primarily interpreted within the framework of the HR policy of the enterprises.

\section{Limitations}

When selecting the case studies, a certain "down-to-earth" attitude was necessary. Because of the need of a high number of interviews, only a few enterprises were willing to take part in the study. As it was not possible to consider case studies likely to yield different results, the selection of case studies represents a methodical deficiency. In the subsequent research process, the falsification of our results was therefore necessary. As we neither intended to test the hypotheses nor to generate them, there is a high demand for further research. It was our goal to bring light in the concepts of the relationship between employer behaviour and social exchange relations, which has not received much scholarly attention. The next step should be to generate and test hypotheses to deepen our understanding of the theories and concepts used here and to develop new ones.

At the beginning of this article, we noted that previous studies unnecessarily emphasised the role of employees in their analyses of functional work relationships. In the present paper, we focused on the quality of employer effort as perceived by the employees. Whether or not the employer's stimuli motivate employees to provide higher contributions was not directly measured; if anything, only assumptions could be made concerning this matter. From our perspective, it can be reasonably justified that satisfied employees are more willing to make the contribution that is expected of them (Martin \& Bartscher-Finzer, 1998). We also could not and did not want to show how individual facets of the OCB of employers and employees interrelate.

\section{Lessons learned}

A good work relationship in SMEs is not characterized by a convenient social reciprocity, but it is the basis for a functional, social collective. The results from the case studies indicate that the determinants of a good work relationship (work, love, money) investigated here can complement or offset one another in different ways. An increase in terms of money, for example, does not automatically strengthen the social collective (love) and can even reduce the work relationship to a basic exchange relation. An increase of love strengthens the work relationship and leads to a more positive interpretation of other rewards (money). As mentioned before, a good work relationship is based on the foundational structure of exchange, which offers guidance and contributes to the development of trust. Violations upon this structure are likely to lead to disruption in the system. In the case studies discussed here, the phenomenon can be seen in multiple areas, e.g. in the introduction of new and "fairer" assessment and reward systems. To foster the fairness, management creates systems that do not align payment with the presented performance anymore. In none of the enterprises shaped by social reciprocity did the employees welcome this measure. In contrast, they per- 
ceived this as a threat to their social reciprocity, and the majority rejects this kind of system. Controlling is not a good fit, as it is likely to change the foundational orientation of the work relationship for the worse. All parties involved rely on trust, and instrumental controls tend to weaken this kind of trust.

Work relationships are also always a struggle for limited resources, a definition of input and output. All parties need room to work out their conflicts of interest, to always renew the sense and purpose of the enterprise as a collective project. The room for necessary arguments about the best path to collective success is a prerequisite for a long-term relationship that can endure conflicts and offer possibilities. Employees do not want managers who simply downplay conflicts of interest or who prefer "management by appeasement." Managers are expected to be honest and stand up for the enterprise. In some case studies, the fight was even cultivated; the employees spoke proudly about conflicts with superiors. The work relationship is not an "oasis of wellbeing" for employees, but rather a space to fight for a successful cooperation. In this sense, conflict has an important function in working relationships.

Social exchange means, people are not treated as a cog in the wheel, but as human beings. The employees feel like organizational citizens and are closely connected to the organization (Martin \& Bartscher-Finzer, 1998). Tasks at work are the result of co-orientation, that is, an orientation concerning the collective well-being of all individuals involved in the enterprise. Since co-orientation is connected to a large effort, fixed values and behavioral rules emerge in these kinds of work relationships, which provide work relief (Martin, 1998). Values add stability to relationships and turn work into a behavioral guideline for new members. Co-orientation is, as perceived by participants in the study, not voluntary but obligatory: "One has to be able to rely on one another." When the foundations for a good relationship are laid down, constantly checked and reproduced anew in social exchange, all individuals are likely to contribute voluntarily. Employers do not need to offer a wide range of rewards but simply have to complete their tasks as reliable partners and follow the norms, which have been established through and continue to guarantee social reciprocity. Employees, in turn, can focus on their respective tasks. Whether an exchange truly is fair and reciprocal is not always easy to say, as exchanges are constantly interpreted in light of the specific rules and orientation patterns of the organisation.

If and in what form a performance can be positively attributed to the employer depends on the definition of the situation, which, in turn, is shaped by the quality of the social relationship. The type or level of performance is not as important as the quality of performance, the performer's intended purpose, or the prior knowledge of the recipients. Love, therefore, has the function as the determining factor of the situation's definition. To interpret individual actions without connecting them to the collectively shared orientation system is likely to lead to misunderstandings. In one of the enterprises investigated in this study, the new management was surprised at the level of employees' discontent due to a few lay-offs due to internal restructuring: "Now some people are being laid off, and the mood takes a hit. I don't understand it." The limited lay-offs of a few hundred employees are barely of consequence, but the statement given above points to a break in the structures of social expectations that are deeply anchored in the organisation (Becke, 2008, p. 77). Employees can interpret 
these lay-offs as a violation of the norms based on the social reciprocity. In this respect, our findings are in line with those of other studies on the concept of perceived organizational behavior (POS). In their review of the literature on POS, Eisenberger and Rhoades (2002) emphasized fairness, supervisor support and favourable job conditions as central antecedents for POS. Our findings give a nuanced perspective on "favourable job conditions" and might have implications for the development of organizational support theories.

\section{Conclusion}

Our study shows that functional social exchange relationships in SMEs are likely to be more important than monetary aspects and that violations of social reciprocity norms may disrupt the balance of work relationships. Using the case studies, we described the employer behavior that is expected by employees from their distinct perspective. Social reciprocity and trust are essential elements at the social level. Furthermore, identification and leadership can also be easily attributed to the human component of work relationships. Simply the desire for orientation (work relief) can be attributed to the level of work. Leading figures likewise provide orientation and guidance. The characteristics of SMEs also need to be considered here. The informality of many organisational interactions and close personal contact between enterprise leadership and employees (Kamen, McCarthy, Gulbro, \& Tucker, 2001) is a prerequisite for the development of orientation and trust. Personal and honest communication begins when the individuals trust another and the relationship, rather than profit, is the primary focus. Owner-led enterprises in Germany, due to their integration of the owner into day-to-day operations, rely on and encourage social closeness among employees. As a result, a social relationship develops, and this was the focus of the present paper. In their study, Kotthoff and Reindl emphasised that almost all the investigated employees display the willingness to engage in a communal social order that is not only achieved when the employer one-sidedly dismisses social closeness (1990, p. 361). Our proceeding and the results are to be seen within the mentioned general conditions.

One of the questions that has yet to be answered is whether other socio-cultural parameters only lead to a different manifestation of the basic need for social reciprocity or whether they result from employees' need for closeness. As suggested by the result of this study, it is to be expected that the need for social reciprocity is inherent to employees regardless of company size or culture. Employer behavior is also likely to affect the work relationship in a positive manner. Already the manifestation of needs and the specific arrangements of requirements will exhibit differences. Employees who can barely feed themselves and their families because of their low wages probably do not strive for self-actualisation at work or for social closeness with the entrepreneur.

Nevertheless, based on the results of our study, especially the lack of evidence for the relationship that was just described will show clear deficiencies. Our methods can also be used to examine large enterprises in modified form. The lack of contact between employees and management makes the process of identification more difficult. Large enterprises attempt to address this insufficiency with other measures. Whether or not identification without the connection to a specific person is possible was not 
the subject of our study but, as indicated by our results, is doubtful. Using case studies, it became apparent that the contributions and commitment of employees depend on efforts of the "boss" and others. In large enterprises, standardisation and bureaucracy prevent, at least to some extent, open and honest communication, obscure the overview, and thus, the individual responsibility of all those involved in the collective project decreases, which makes it the project of the others (this was repeatedly described in the interviews).

\section{References}

Ashforth, B.E., \& Mael, F. (1989). Social identity theory and the organization. Academy of Management Review, 14(1), 20-39.

Barnard, C.I. (1938). The functions of the executive. Cambridge, Mass.: Harvard.

Baron, J.N., Burton, M.D., \& Hannan, M.T. (1996). The road taken: Origins and evolution of employment systems in emerging companies. Industrial and Corporate Change, 5(2), 239-275.

Bateman, T.S., \& Organ, D.W. (1983). Job satisfaction and the good soldier: the relationship between affect and employee "citizenship". Academy of Management Journal, 26(4), 587-595.

Becke, G. (2008). Soziale Erwartungsstrukturen in Unternehmen: zur psychosozialen Dynamik von Gegenseitigkeit im Organisationswandel. Berlin: edition sigma.

Berger, U., \& Bernhard-Mehlich, I. (2006). Die Verhaltenswissenschaftliche Entscheidungstheorie. In A. Kieser \& M. Ebers (eds.), Organisationstheorien (pp. 169-214). Stuttgart: Verlag W. Kohlhammer.

Brief, A.P., \& Motowidlo, S.J. (1986). Prosocial organizational behaviors. Academy of Management Review, 11(4), 710-725.

Brief, A.P., \& George, J.M. (1992). Feeling good - doing good: A conceptual analysis of the mood at work-organisational spontaneity relationship. Psychological Bulletin, 112(2), 310-329.

Bunge, M. (1967). Scientific research. Band 1 und 2. Berlin: Springer.

Cyert, R.M., \& March, J.G. (1963). A behavioral theory of the firm. New Jork: Englewood Cliffs.

Eisenberger, R., Armeli, S., Rexwinkel, B., Lynch, P.D., \& Rhoades, L. (2001). Reciprocation of perceived organizational support. Journal of Applied Psychology, 86(1), 42-51

Eisenberger, R., \& Rhoades, L. (2002). Perceived organizational support. Journal of Applied Psychology, 87(4), 698-714

Elster, J. (1989). Nuts and bolts for the social sciences. Cambridge: Cambridge University Press.

Flanagan, J.C. (1954). The critical incident technique. Psychological Bulletin, 51(4), 327-359.

Gouldner, A.W. (1984). Reziprozität und Autonomie. Frankfurt a.M.: Suhrkamp.

Hertel, G., Bretz, E., \& Moser, K. (2000). Freiwilliges Arbeitsengagement: Begriffsklärung und Forschungsstand. Gruppendynamik, 31(2), 121-140.

Jaeggi, R. (2005). Entfremdung: zur Aktualität eines sozialphilosophischen Problems. Frankfurt a.M. u.a.: Campus.

Jochims, T. (2010). Personalpolitik in mittelständischen Unternebmen. Personalpolitische Konfigurationen und organisationale Dissonan₹: München und Mering: Hampp Verlag.

Kambartel, F. (1989). Philosopbie der humanen Welt: Abhandlungen. Frankfurt a.M.: Suhrkamp.

Kamen, V., McCarthy, A.M., Gulbro, R.D., \& Tucker, M.L. (2001). Bureaucratic and high commitment human resource practices in small service firms. Human Resource Planning, 24, 33-44.

Kotthoff, H., \& Reindl, J. (1990). Die soziale Welt kleiner Betriebe. Göttingen: Schwartz.

Kotthoff, H. (2010): „Betriebliche Sozialordnung" als Basis ökonomischer Leistungsfähigkeit. Wirtschaftssoziologie - Kölner Zeitschrift für Soziologie und Sozialpsychologie, 49, 428-446.

March, J.G., \& Simon, H.A. (1958). Organizations. New York: Wiley.

Martin, A. (1998). Das Modell der Handlungsentlastung. Personalpolitik als Widerspiegelung von Entscheidungsstrukturen. In A. Martin \& W. Nienhüser (eds.), Personalpolitik. Wissenschaftliche Erklärung der Personalpraxis (pp. 113-154). München und Mering: Hampp Verlag.

Martin, A. (2003). Arbeitszufriedenheit. In: A. Martin (ed.), Organizational Behaviour - Verbalten in Organisationen (pp. 11-33). Stuttgart: Kohlhammer.

Martin, A. (2011). Handlungstheorie. Grundelemente des menschlichen Handelns. Darmstadt: WBG. 
Martin, A. (2006). Die subjektive Beurteilung der Arbeitsbeziehung in unterschiedlichen Beschäftigungsverhältnissen. Die Betriebswirtschaft, 66, 146-176.

Martin, A., \& Bartscher-Finzer, S. (1998). Die Erklärung der Personalpolitik mit Hilfe der AnreizBeitrags-Theorie. In A. Martin \& W. Nienhüser (eds.), Personalpolitik. Wissenschaftliche Erklärung der Personalpraxis (pp. 113-154). München und Mering: Hampp Verlag.

Martin, A., \& Behrends T. (2005). Betriebsgrößenbedingte Unterschiede in der Personalarbeit von Unternehmen. In R. Schulte (ed.), Ergebnisse der Mittelstandsforschung 2, (pp. 151-183). Münster u.a.: LIT Verlag.

Moorman, R.H., Blakely, G.L., \& Niehoff, B.P. (1998). Does perceived organizational support mediate the relationship between procedural justice and organizational citizenship behavior? The Academy of Management Journal, 41(3), 351-357

Motowidlo, S.J., \& van Scotter, J.R. (1994). Evidence that task performance should be distinguished from contextual performance. Journal of Applied Psychology, 79(4), 475-480.

Organ, D.W. (1988). Organizational citizenship behavior: the good soldier syndrome. Lexington, Mass. u.a.: Lexington Books.

Pongratz, H.J., \& Trinczek, R. (2010). Industriesoziologische Fallstudien. Entwicklungspotenziale und Forschungsstrategie. Berlin: edition sigma.

Rousseau, D. (1995). Psychological contracts in organizations: Understanding written and unwritten agreement. Thousand Oaks: Sage.

Sennet, R. (2005). Die Kultur des neuen Kapitalismus. Berlin: Berlin Verlag.

Tajfel, H. (1982). Gruppenkonflikt und Vorurteil. Entstehung und Funktion sozialer Stereotypen. Bern u.a.: Hans Huber.

Tsui, A.S., Pearce, J.L., Porter, L.W., \& Tripoli, A.M. (1997). Alternative approaches to the employeeorganization relationship: Does investment in employees pay off? Academy of Management Journal, 40(5), 1089-1121.

Voswinkel, S. (2005). Reziprozität und Anerkennung in Arbeitsbeziehungen. In F. Adloff \& S. Mau (eds.), Vom Geben und Nebmen. Zur Soziologie der Reziprozität (pp. 237-256). Frankfurt/New York: Campus.

Wächter, H. (2011). Employer behavior - grasping a phantom. Management Revue, 22(4), 325-330, DOI 10.1688/1861-9908_mrev_2011_04_Waechter.

Yin, R.K. (2014). Case study research: Design and methods. Los Angeles, Calif.: Sage.

Yin, R.K., \& Davis, D. (2007). Adding new dimensions to case study evaluatios: The case of evaluating comprehensive reforms. In G. Julnes \& D.J. Rog (eds.), Informing federal policies for evaluation methodology (New Directions in Program Evaluation, No. 113, pp. 75-93). San Francisco. JosseyBass. 